\title{
MUSIC MANAGEMENT- NEW OPPORTUNITIES NEW CHALLENGES
}

\author{
Dr. Anjana Saxena \\ Professor - Economics \\ Govt. M.L.B. Girls P.G. College, Indore (M.P.)
}

The transition to digital is changing the music industry. As technology has advanced over recent years, the music industry has consequently undergone a drastic change in the way it operates. This industry-wide shift has its pros and its cons: On one hand, the internet serves as an incredible platform on which anyone can exhibit their talent and potentially build a fan base. On the other hand, the presence of millions of people attempting to do so make it more and more difficult for any one person to stand out, and the reality of file sharing and illegal downloading makes the financial aspect of music much more complex. Regardless of one`s opinion about the road that the music industry has traveled down, a music manager must be flexible enough to keep up with the changes that the industry undergoes. The meaning and role of a "manager" has changed drastically over the last decade as the traditional business model has given way to the "new" music business Traditionally a manager managed an artist's efforts to get signed to a label and once signed, he/she managed the relationship between the artist and the label. But given the state of labels today the unsigned artist must assume that he/she will never be signed and build a career accordingly. A traditional manager is often unable and ill - equipped to successfully manage and develop an artist's career in the new environment.

\section{THE MODERN MANAGER NEEDS TO POSSES}

1 Internet literacy and deep knowledge of how to use online Marketing, promotion and distribution of tools/services.

2 The ability to develop and execute strategic partnership with brands, businesses and other blue ocean partners.

3 Knowledge of independent financing alternatives and an understanding of financial models.

4 The ability to pull together a creative team around the artist.

5 Relationship with booking agents and others who can help create live performance revenue.

6 An entrepreneurial spirit-since every young artist is really just a start-up company.

Even managers of established artists find themselves in need of re-education in light of the fact that their artists are voluntarily leaving their long time record labels. Many established managers are unable to overhaul their skills to really serve their artists.

Because of this reality co-management deals should become increasingly popular as artists realize that they are best served by both the established manager with valuable connections and an understanding of the live business, as well as the young manager who is more capable of 


\section{INTERNATIONAL JOURNAL Of RESEARCH -GRANTHAALAYAH

creating and managing the artist's online social media presence, digital distribution and other facets of the "new" music business.

A good manager in the new music business therefore understands his/her own assets and limitations and is willing to collaborate with others whose skill sets compliments his/her own for the benefit of the artist. Finding a good manager has always been very difficult. One of the questions frequently asked of the Music managers forum is "Where can I get a manager"? The old traditional music industry is collapsing and managers need to look beyond this 'one track' approach and learn new skills.

\section{HOW TO BECOME MUSIC MANAGERS}

Learning how to become a music manager is one of the toughest things to do. In fact it depends on the artists who are managed and their partnership with them.

The right attitude is important to understand how to start music management. If you expect to start funneling cash to your bank account instantly, you are in for a rude awakening. Just like it takes patience and preservance to launch a music career. It takes drive, ambition and stamina to become a music manager.

If you want to get a start in the music business and work your way up to a management position, you will need to become a music industry expert and learn how to motivate and promote budding artists.

Step I - According to seasoned managers a passion for music will be the drive to get into management. Go to live shows and decide the type of music that you would like to promote.

Step II - Have an outgoing personality as a music manger you will need to be an advocate for the band, a negotiator on contracts and an authority on your band's music. Foster a social nature that helps you to network and market music.

Step III - Take business classes. Music managers should also develop their business sensibilities through classes, degree programs with a focus on business administration. Music managers earn their money from a percentage of profits so they must be good at business to succeed.

Step IV - Read industry journals, books, newspapers and websites. Read blogs and books written by current and former managers. After a few months to a year of reading industry news, you should be fluent enough to begin making music industry contacts.

Step V - Get an entry level job in the music industry. You may need to move to large cities to increase your chances of getting a job. Some labels and talent agencies filter their employees through work experiences internships.

Step VI - Move up the ladder at a music business. Alternatively, you can find a mentor manger spend 1 to 2 years in close contacts with music mangers to learn how they book venues, tours, recording contacts and endorsements.

Step VII - Start managing an act you are passionate about. If you believe in the artist, it will be easier to help them navigate through the music business. Start by managing a local band's tour local gigs or new album. Part of being an artist manger is to learn how to manage people. Artist 


\section{INTERNATIONAL JOURNAL Of RESEARCH -GRANTHAALAYAH

manager must have excellent interpersonal skills and they occasionally act as a voice of authority.

Step VIII - Market the music instead of trying to make the music fit the area or venue. Most musicians have a personal attachment to their art. You will find more success researching the sight audience than trying to lead the music in a different direction.

Step IX - Take on new acts as you develop your contacts. You will need to learn to juggle many different tasks, so hire employees as you are able to oversee more groups. However you may choose to always remain a hands on manager, instead of creating a talent agency or moving up in a music company

The best way to start a music management is to begin by representing a client with whom you already have a strong relationship. Most artists benefit more from having a trusted friend or family member oversee their career in the early years than from working with an experienced music managers. The music management skills can be learned faster than the trust can be earned. Especially in a business where hundreds of artists compete for the attention of each working music manager.

Ultimately starting a music - management career may depend upon your success with the first few acts. If you are able to help them make money and rise to success. You are likely to be offered more contracts or a larger cut of the profits.

\section{REFERENCE -}

1 "When does my band need a manager" -Getfegned.com July 162013

2 "Why music won't be saved by social media." Hybebot.com (2013) March 9, 2013

3 "Making money from music" -Martin kupp, Jamic Anderson and Jorge Reckhenrich _ case study

4 "The Financial times LTD (2011) Accessed March 7, 2013 